\title{
The Application of 4/3/2 Technique To Enhance Speaking Fluency Of EFL Students In Indonesia
}

\author{
Hery Yufrizal \\ The University of Lampung, Indonesia
}

\begin{abstract}
The aims of this areticle are firstly to explore the application of $4 / 3 / 2$ technique in enhancing learners' speaking fluency and to exspose how fluency practie can help students' improve their speaking ability. The research was conducted at a language school in Indonesia involving 20 first year students at the University of Lampung The students were divided into two teams the speaker team and the listener teams. The speaker team was given the opportunty to speak for three speaaking turns: four minutes, three minutes and two minutes. Later, the teams change roles the speakers become listeners, the listeners became speakers. The topics of the talks are determined by the group prior to the application or the actitivites. The results showed that students improve their speaking accuracy and fluency.during three speakiing turns.
\end{abstract}

Key Word: 4/3/2 Technique, fluency, accuracy,talks

\section{INTRODUCTION}

The final aim of teaching English in Indonesia is to enable the students to communicate in English both in written and orally. A lot of strategies have been designed by English teachers and language education experts to fulfill students' need for languge education. In Indonesian education system the aims of teaching Engish are divided into several divisions. Englsh as a compulsory subject is given to the first year students of junior high school (age eleven to twelve year od) up to the third year students of junior high school (sixteen to sevenyeen year oled students). Some schools start teaching English at the earlier age as an optional subject, Some higher education institutions provide English as a compulsory subject for one semester some provide longer time for the teahing of English.

In the application, students are asked to have conversations by imitating the conversation models they hear, usually done in front of the class.This pattern of conversation is done repeatedly. While the ability of students to communicate orally without being bothered by the patterns being taught are still untouched in its planning. Therefore, eventhough students are able to comprehend texts, they tend not be able to express their ideas orally, while the final aim of language learning is to ebable students to master the language rules while being able to use the language for communication.

Therefore, we still need a lot of attempts to try various techniques and strategies that will enable students not only be able to speak English but also to communicate in English.. One of the techniques that can be used is 4/3/2 technique, which according to Zhou (2006:19), this technique is not only able to improve students' speaking Englsh but also to increase the students' accuracy in speaking English. This technique is also able to encourage students to use English without being worried of making any mistakes. 
The 4/3/2 tecniqu was designed by Maurice (1983) to improve students' oral communication fluency. This technique has the meanig of repeating the content of the talk to different listeners without being worried of what has been said. The characterisics of this techniquen is having a speaker(s) and the same content of the speech, but different listener and the decreasing of taking time. (Zhang 2002: 420). In its application, this technique can be shifted into 3/2/1 when the student's ability in speaking English is still very low as practiced by Zang (2002).

In its application, the $4 / 3 / 2$ technique gives opportunity to students to get across their ideas to three different listeners for four minutes, three minutes, and two minutes with the same topic but different listeners. Giving the opportunity to speak the same topic to different listener will enable students to express their ideas without being afraid of making any mistakes.

On the other hand, the rapid progress in information technology has been far beyond the expectation. In almost all aspects of life of students are ornamented with the presence of handphones on multi media basis. It is not surprising that almost all students posses handphones both for entertainmen purposes and for other social media purposes. The use of multi media cellular phone is indespensable from the objective of teaching and learning English, i.e. to enable the students to communicate orally and in written..

\section{Speaking fluency and accuracy}

Speaking fluency and accuracy are two main objectives of a second or foreign langage learning objectives (Ur 1996: 103). Fluency is based on meaning while accuracy is based on language forms (Ur 1996; Brumfit 1984; Stern 1992). Both concepts although seem to contradic, they actually complement to each other with regard to what is the focus of second or foreign language learning and teaching. The question raised is whether the second or forein language is stressed on the fluency of using language or on the accuracy of using language rules. Some experiments showed that stressing on the speaking fluency and accuracy bear the same conaequences (Skehan 1996; He \& Wang 2003). There are two ways to answer the question of which should be prioriterized between the speaking accuracy or fluency. Some researhers believe that speaking accuracy is the only way to improve one's speaking ability (Nunan 1999/2001, Higgs \& Clifford 1982). Schmidt (1992) stated that fidgin English is not a kind of added value of communicaing ability because the language form does not have the communicative from the native speakers (Zhang 1999a) and does not fulfil the expectation and dorm of the native speaker's expecrarion (Sajavaara 1987). There are many ways to achieve language use accuracy. For example by decreasing the influence of grammatical accuracy through learning (Ellis 1999) Grammar learning should function as a vehicle to the ability to communicate (Nunan 1993) while the increase of consciousness-raising training could result in lng term effect useful for improving communication ability. Long (2015) suggested the emphasis on form focus teaching during the teaching of on communicative basis during the teaching of language on communicative base by delaying the teaching certain language forms that can cause difficulties to communicate.

On the other hand, some researchers beleve that learning language by stressing on fluency is an appropriate way to improve one's language ability (Brumfit 2000). While Zhang (1999) found that stressing on $U$ form in the mastery of English in China. As said that the development of students'grammar mastery in China follow a stable grammatical pattern. This means that the development of students' grammatical ability in China has been patterned in such a way that it becomes easily predicted. While language learning on speaking fluency base is signified by ability to accept and follow up the information easily (Ur 1999) Language learning focusing on the use of language fluency chracteristics. Meanwhile language learning that focuses on 
grammatical accuracy, vocabulary choice and other language aspects. Some methods and techniques that focus on fluency are among others 4/3/2 tehnique and other similar techniques. (Arevart \& Nation 1991)

\section{The 4/3/2 technique}

The 4/3/2 was created by Maurice (1983) to improve the oral language fluency. The technique implies the repetition of the content of the talk by the speaker to different listeners in terms of minute to talk. The characeristtics of this technique are it has the same speaker and the same content of speech, different listener and the decreasing time of speech. (Zhang 2002, Arab, 2006). In its implication the technique can be shifted into $3 / 2 / 1$ when the language ability of the students who apply it is still too limited.as applied by Zang (2002).

In its implementation, the 4/3/2 technique provides opportunities for students to deliver their ideas to the speech counterpart with a duration of four minutes, three minutes, and two minutes with the same topic but different counterparts. Giving the opportunity to speak in three different length of speech will enable students to express what they want say without being afraid of making mistakes.

\section{Learning to Speak Using 4/3/2 Technique}

There are some steps that must be followed in the implementation of $4 / 3 / 2$ technique beside those general steps in Learning English such as the explanations on students' duties

\section{a. Topic deternination}

Topic determination is underttaken aftar the students have understood what tthey ara supposed to do. The topic chosen can be single topic that should be selecterd by all students or it can be some alternative adjusted to the curriculum so that a topic selected by one student can be different from other. The topic selected is adjusted to students' ability and interest. Some common topics selected are 'me and my family', 'the most interesting experience I ever have', 'my hobbies', 'TV Program, etc.

\section{b. Drafting the talk}

The second step in accomplishing 4/3/2 is drafting the talk. After the students decided the topic they choose, the students are asked to arrange draft (not a complete composition) about what they are suppose to deliver. The students are asked to compose an outline to deliver a speech for four minuts. The time alocated for drafting the speech is 10 to 15 minutes.

\section{c. The division of participants in to speakers and listeners}

After all students finished drafting for talk, the students are divided into pairs. The composition of of the seating arranement is as following: 
The scheme for seating arrngement for talk in pairs

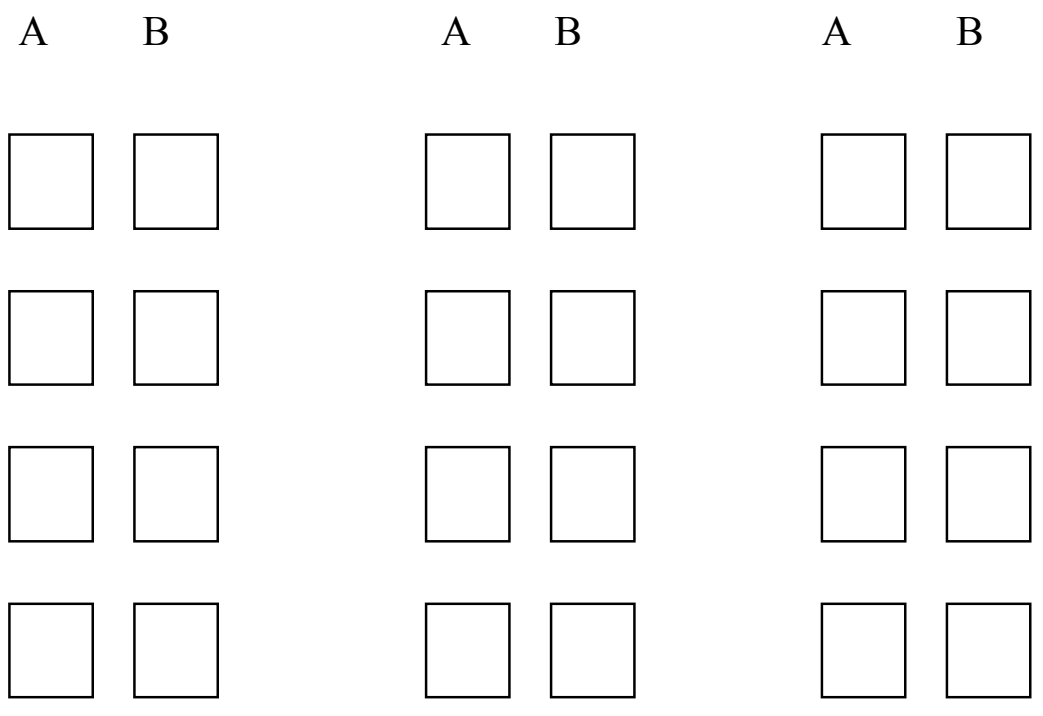

A the lines for students function as speakers, while B is the line for students function as speakers.

After the students are placed in their seats, the lecturer set the time of speaking for four minutes. The students who get turn to speak, deliver their speech while the students whose functios are listeners pay attention the talk without giving any comments but showing the signal that he or she is listening. After the four minute is over, the speaker stop talking.

After the three minute is over, the speaker moves to the second listener and begin the same message.

\section{d. Pair shfting}

After the three minute talking, the speakers are asked to shift to find another talking partner. The same procedure is applied when the student speakers shift the talk and take thir turn speaking in two minutes.

\section{e. Shifting roles}

After all students who got their roles as speaker speakers have accomplish their job, the students' role are shifted. Those who become speakers in the first turn now are shifted into listeners and vise versa. This process is accomplishe until all students finish their jobs.

\section{RESEARCH PROCEDURES}

This research is a quasi experimental in nature. It has an experimental group, i.e without a control group. It seeks to anwer a research question whether the actvities done by the sample produce the same amount of phenomenon it seeks to answer. The subjects of the research were the first year studets of English Department, the University of Lampung Indonesia. It seeks to answer a research quesion whether or not the subjects of the research produce fluency and accuracy when implementing the $4 / 3 / 2$ technique.

The research procedures are the students are divided into speakers and listeners. The speakers are assigned to talk to listeners in 4/3/and 2 minutes talking with the topics chosen by the speakers. Students then change roles, speakers became listners, listners become 
speakers who would speak for four, minutes, three minutes and two minutes. There are three alternative topics that stydents can choose to be deleverd in their speeches. The alternative topics are: Me and my hobbies, why I choose English as my major, and The most exciting experence I've ever experienced.

\section{Language elements produed}

\section{RESULTS}

Language element produced are divided into two parts: fluency and accuracy. The reults are as follow:

\section{a. Fluency}

\section{i. words per minute}

Table 4.1 illustrate the number of words per minute produced by students for the first turn (four minute talk), the second turn talk (three minutes) and the third turn talk (two minutes)

Table 4.1 Number of words produced in three talks Descriptive Statistics

\begin{tabular}{|l|r|r|r|r|r|}
\hline & N & Minimum & Maximum & \multicolumn{1}{c|}{ Mean } & Std. Deviation \\
\hline wpm4 & 20 & 23,00 & 121,25 & 71,6750 & 26,90797 \\
wpm3 & 20 & 26,00 & 131,00 & 75,4901 & 27,14023 \\
wpm2 & 20 & 28,00 & 119,00 & 81,7500 & 27,45882 \\
Valid N (listwise) & 20 & & & & \\
\hline
\end{tabular}

Table 4.1 shows that the number of words produced by students per minute in the first turn talking (four minute) talk is 71,67. On the second turn the average number of words per minute produced was 75,49 , and the third talk time was 81,75 . Thus, it can concluded that there is a constant increase in the number of words produced in each talk turn

\section{ii. The number of pauses}

Tabel 4.2 The number of pauses) in three talk turns Descriptive Statistics

\begin{tabular}{|l|r|r|r|r|r|}
\hline & $\mathrm{N}$ & Minimum & Maximum & \multicolumn{1}{c|}{ Mean } & Std. Deviation \\
\hline pauses4 & 20 & 3,00 & 47,00 & 14,5500 & 11,39471 \\
pauses3 & 20 & 1,00 & 17,00 & 7,4500 & 4,78457 \\
pauses2 & 20 &, 00 & 15,00 & 5,4000 & 4,22275 \\
Valid N (listwise) & 20 & & & & \\
\hline
\end{tabular}

From the number of pauses, in the first turn the average number of turn taken by the studet was $11,39.14,78$ pauses were produced in the second turn, while in the third turn students produced 4,22 pauses. Therefore, it can be concluded that that there was a decreasing number of pauses produced in the first, second, and third turns of talk.

\section{iii Number of hesitations}

Tabel 4.3 The number of hesitations produced in three talking turnss Descriptive Statistics

\begin{tabular}{|l|r|r|r|r|r|}
\hline & $\mathrm{N}$ & Minimum & Maximum & Mean & Std. Deviation \\
\hline hesitation4 & 20 & 1,00 & 20,00 & 5,5500 & 4,61662 \\
hesitation3 & 20 &, 00 & 12,00 & 4,0500 & 3,28433 \\
hesitation2 & 20 &, 00 & 10,00 & 2,7000 & 2,75490 \\
Valid N (listwise) & 20 & & & & \\
\hline
\end{tabular}


The average number of hesitations resulted from the first talking session was 5.55 hesitations in the first. It decreases into 4.22 hesiitations in the secod turn and into 2.70 in the third session of the taks. Therefore, it can be inferred that there a constant decreaing number of hesitations produced by subjects during the first, second, and third turn of studets' talk.

\section{iv. The number of false-starting}

Tabel 4.4 The number of false staring Descriptive Statistics

\begin{tabular}{|l|r|r|r|r|r|}
\hline & $\mathrm{N}$ & Minimum & Maximum & \multicolumn{1}{c|}{ Mean } & Std. Deviation \\
\hline false4 & 20 &, 00 & 7,00 & 1,8000 & 1,60918 \\
false3 & 20 &, 00 & 7,00 & 1,8000 & 1,82382 \\
false2 & 20 &, 00 & 4,00 &, 8500 & 1,03999 \\
Valid N (listwise) & 20 & & & & \\
\hline
\end{tabular}

The average number of false staring resulted from the first talking session was 1.8 false starting in the first. It remains 1.8 false startings in the secod turn and into .88 in the third session of the talks. Therefore, it can be inferred that there a constant decreaing number of false startings produced by subjects during the first, second, and third turns of students' talk.

\section{v. The number of L1 use}

Tabel 4. 5 The number of $\mathrm{L} 1$ use Descriptive Statistics

\begin{tabular}{|l|r|r|r|r|r|}
\hline & $\mathrm{N}$ & Minimum & Maximum & \multicolumn{1}{c|}{ Mean } & Std. Deviation \\
\hline L14 & 20 &, 00 & 9,00 & 1,8000 & 2,54641 \\
L13 & 20 &, 00 & 5,00 &, 9500 & 1,27630 \\
L12 & 20 &, 00 & 5,00 &, 7000 & 1,49032 \\
Valid N (listwise) & 20 & & & & \\
\hline
\end{tabular}

The average number of L1 uses resulted from the first talking session was 2.54 L1 uses in the first. It decreases into 1,27 L1 uses in the secod turn and into 1.49 in the third session of the taks. Therefore, it can be inferred that there is a constant decreaing number of L1 uses produced by subjects during rhe first, second, and third turns of students' talk.

\section{b. Speaking Accuracy}

Speaking accuracy is defined in terms of the number of errors committted by students in each talking turn. The following is the number of accuracy produced by students during the sesssins.

\section{Self repair on single word}

Student revises a mistake in producing one word. Misal: My name is Wulan, I was born in...on April 1997 (pada pembicaraan pertama)

For example: My name is Wulan I was born on April 1997.

\section{Self repair on clause}

Student revise the error commiterd in the first talk

4 minute talk: What I dream ...eee...before...uuuh...what I dream in the future first...uhhm in the first, I am going to continue...

3 minute talk: I choose uhh the two option about what I dream in the future... first...uhh...in uhhh rational

2 minute talk: I choose the second option what I dream in future...as for the...uhhh...the.... for my rationale dream. 


\section{Self repair on sentence}

4 minute talk: and my mother, my mother's name is Mutia. She was born in Medan on... September 8th 1964. And then now he works as a house wife... you know house wife. He...she doesn't work uhhh anywhere.

3 minute : "And.then... my mother, my mother's name is Mutia. She works...uhh she was born in Medan, on September 8th 1964. And then uhhh she is a house wife, you know that she doesn't work.

2 minute talk:: And my mother's name ia Mutia. She was born in Medan, on September 8th 1964, and now she has been 52 years old

\section{DISCUSSION}

According to research done by Movahed and Karia (2014) the 4/3/2 technique has three main advantages: improving the speaking flency, increasing grammatical accuracy, and intensifying control over the content of the talks.

\section{$4 / 3 / 2$ technique increase fluency of talk}

There are 8 cases that show $4 / 3 / 2$ technique was successful to improve the speed of talk. The first case study showed that there are improvements of language production by students in in the first turn (four minute talk) to the second turn of talk'

The students talk in the average speed of 86 words per minute on the first turn talking. It then increaed to 100 words per minute in the second turn, then the speech increased to 122 word per minute in the third turn of the talk.

The research also shows that there was an increase in the number of words produced by students in the first four minute turn. Students produced 71.67 words per minute in first turn talking. It then increased to 75.words per minute in the second turn. While in the third turn talking students produced 81.75 words per minute in the third talking turn. Nation (1989) stated that $4 / 3 / 2$ decreases the number of hesitation from 1 percent to 67 percent of hesitation in the first, second and the third talking turns.

\section{4/3/2 technique strenthen grammatical power}

This technique requires the participant to talk about the same topic to different listeners. Of course, there would be some repetitions made by the speakers in the first, second, and third turns because the topic is similar without new information delivered. Nation (1989) stressed that from 8 studies, 4 of which showed the same errors were found in each turn.This shows that there are some accuracy improvements underr two conditions firstly, repetitions improve students' self reliance. Secodly, according to Nation (1989) the technique has the local inflence in the talk that it enables students to monitor their performance.

\section{4/3/2 technique increaes control over content}

When we talk, we often use unnecessary words or phrases. By giving time limitation to talk, the speaker tries to deliver the intention of the talk directly without using unecessary ornaments. This will increaase the complexity and avoid ambiguity in the talk. From the data obtained, students in this study are able to cut off 144 unnecessary words in the third turn taking. This confirms the research by Nation (1989), Movahed and Karia (2014) that by limiting the talk, the studens are 'forced' to transfer information concisely and efficiently.

\section{4/3/2 technique improve students motivation to talk in English}

One of the characteristics of Indonesian students learning English is their lack of confidence in using English for communication. (Alissyahbana, 1989). Through 4/3/2 technique students are 
motivated to talk in English becaue they have to talk to three different listeners. They are forced to speak more and faster due to the limitation of time given.

\section{CONCLUSIONS}

Based on the results of the analaysis, some conclusions can be drawn. The $4 / 3 / 2$ technique improve the speaking flueny, grammatical accuracy and control the content of the talk. The result of study showed that the number of words produced by students increased constantly during the first, the second and the third turn. Additionally, the data showed the number of pauses, the number of hesitations, the number of false startings and repetitions are kept on decreasing from the first, the second, and the third turn taking.

Additonal conclusions that can be drawn from the study are:

a. The 4/3/2 technique provide opportunities for students to self reflection over their speaking English ability.

b. The $4 / 3 / 2$ technique provides opportunities for students to train srancsribing therir conversation.

c. The $4 / 3 / 2$ technique gives the opportunity for students do make coding over language aspects.

d. The 4/3/2 technique provides opportunities to do peer review and peer correction.

\section{SUGGESTIONS}

a. Cosidering the fact that the $4 / 3 / 2$ technique can improve students' speaking accuracy and fluency, it is suggested that the technique be applied and developed at all levels of education and learning ability.

b. Consdering that the massive use of cellular phone for learning language, it will be useful for lecturers and students to make use of this tool to improve language learning massively.

\section{References}

Alisyahbana, ST. 1990. The teaching of Engish in Indonesia. In J.M. Britton,R.E Shaffer, and K.Watson(Eds.).

Teaching and Learning English Worldwide. Cleveland. Multilingual Matters, Ltd.

Arevart, S. \& I.S.P Nation. 1991. Fluency improvement in a second language. RELC Journal 1: 84- 95.

Arab, Oudid, 2016. The Effect of the 4/3/2 Technique on Students' Speaking Fluency The Case of First Year LMD Students, Frères Mentouri University, Constantine. Revue EXPRESSIONS n²2. Juillet

Brumfit. C.J 1994. The Practice of Communicatve Teaching. Pergamon Press

Brumfit. C.J 2000. Individual Freedom in Language Teaching. Oxord, Oxford University Press.

Ellis, R. 1994. The study of second language acquisition. Oxford: Oxford University Press

Maurice K. 1983. The Fluency Workshop TESOL Newsletter. !7 (4) 29.

Foster , P . \& P . Skehan . 1996. The influence of planning and task type on second language performance. Studies in Second Language Acquisition $18: 299$ - 323 .

Higgs, T.V. and Clifford, T. 1992. The Push toward Communication. In T.V Higgs (Ed.) Curriculum, Competence, and the Foreign Language Teacher. Pp.57-136. Lincolnwood, IL. National Textbook, Co

Long, M.C. 2007. Problems in SLA Mahwah, NJ Lawrence Erlbaum Associations

Nation, Paul. Improving Speaking Fluency. (1990). Pergamon Press. www.victoria.ac.nz/lals/staff/.../paulnation/1989-Fluency.pdf. $\{$ Online . Available. accessed on December 20, 2011

Nation, P. (1989). Improving speaking fluency. System, 17 (3), 377-384.

Nation, I. Newton, J. (2009). Teaching ESL/ EFL Listening and Speaking. New York: Cambridge University Press. Nunan, D. 1999. Second Language Teacher Education. Cambridge: Cambridge University Press. 
Nunan, D 1993. Second Language Teaching and Learning. Cambrisge, Newbury House.

Sajavaara 1987. Second Language Acquisition in a Study Abroad Context. John Benjamin Publishing Company.

Schmidt. R. Studies in Second Language Acquisition. Cambridge. Cambridge University Press.

Skehan, P. 1996, A framework for the implementation of task- based instruction . Applied Linguistics 17/1: 3862.

Skehan, P. P. Foster.1999.The influence of task structure and processing conditions on narrative retellings. Language Learning 49/1: 93-120

Stern. H.H. Issues and Options in Language Teaching. Oxford. Oxford University Press.

Stren M. 1994. An Introduction to Spoken Interaction. London: Longman Group Limited.

Ur, Penny.1996 A Coutse In Language Teaching. Cambridge University Press

YANG, Y.I.J. (2014a). The Development of Speaking Fluency: The 4/3/2 Technique for the EFL Learners in China. International Journal of Research Studies in Language Learning, 3(4), 55-70.

YANG, Y.I.J. (2014b). The Implementation of Speaking Fluency in Communicative Language Teaching: An Observation of Adopting the 4/3/2 Activity in High Schools in China. International Journal of English Language Education, 2(1), 193-214.

Zhang, Wenzhong. 2002. The Development of L2 Oral Fluency in EFL Classroom Setting. Changsha: Hunan Education Press.

Zhou , Aijie. 2002.A study of the effects of the 4/32 technique on the fluency improvement in oral English. Journal of Guangdong Polytechnic Normal University 2: 102- 105.

Zhou Aijie. 2006.A Further Study of the Effects of the 4/3/2 Technique on Spoken English Production. CELEA Journal 65

\section{ACKNOWLEDGEMENT}

This research was funded by the Faculty of Teaching and Education, the University of Lampung. Therefore, the researher would like to thank to the Dean of the faculty and to the head of Department of Language and Art of the faculty of Teaching and Education for allowing the implementation of the reseaarch.

Hery Yufrizal is currently a senior lecturer at the department of language and art education, FKIP Universitas Lampung. He teaches Second Language Acqusition, Semantics, Pragmatics and Speaking. He got his Ph.D in Applied Linguistics from La Trobe University, Melbourne, Australia. His research interests include: classroom interaction, teachers' development, and discourse analysis. 